\title{
The end of the affair?
}

\author{
Matthew C Kiernan (D) 1,2
}

\section{The time ahead is endless}

As noted by Graham Green in his famous novel The End of the Affair, a story has no beginning or end, and so arbitrarily, we must identify a moment or an experience from which to look back or from which to look ahead. ${ }^{1}$

And so it seems timely for me to consider that moment with JNNP. Does it date back to the influence of my teachers and their teachers, and their contributions to the journal? ${ }^{2} 3$ Perhaps it relates to my own involvement, from undertaking tasks as a reviewer, through to my first publication in JNNP. ${ }^{4}$ Or could it relate to working as part of an Editorial Board or most recently, taking on my role as Editor-in-Chief?

My first interaction with JNNP was during my early clinical training in neurology (figure 1). It made such a mark, that in those days before institutional electronic access, I signed up for my first journal subscription. Every month, the green-clad volume would arrive by mail to Sydney, sent from Tavistock Square in London. From there, I would gradually traverse the landscape of manuscripts and learn. From the identification and processing of neurological history and signs, through to the incorporation of novel investigation approaches; the ways to reach a diagnosis, through to an approach to treatment, with consideration of outcomes. The art of neurology.

Fast forward to 2009, it seemed implausible that I would be asked to take the helm as Editor-in-Chief of this precious vessel, and unlikely that the JNNP would appoint an Australian as its inaugural nonBritish editor. From the outset, I invoked the independent spirit of the larrikin, fuelled by alacrity and unafraid to take a risk. ${ }^{5}$ My plan was to develop an editorial team that would drive the journal further, with greater representation, presence and readership across Europe, Asia and the Americas.

'Bushell Chair of Neurology, Brain and Mind Centre, University of Sydney, Sydney, New South Wales, Australia

${ }^{2}$ Neurology, Royal Prince Alfred Hospital, Camperdown, New South Wales, Australia

Correspondence to Professor Matthew C Kiernan, Bushell Chair of Neurology, Brain and Mind Centre, University of Sydney, Sydney, New South Wales, Australia; matthew.kiernan@sydney.edu.au
And so to the present day, the release of the December issue of the journal, which marks the completion of my tenure as EiC. The privilege of working with such a fine team has magnified the rewards of serving as Editor of JNNP-the jewel in the crown of neuroscience journals. ${ }^{6}$ Afforded this position, it is time to say thanks across a very extended family of contributors, from the journal publishers (particularly Claire Langford, Janet O'Flaherty and Peter Ashman) through to production (Kate Spencer), from commissioning editor Martin Turner through to our team of social media editors, blog writers and podcasters. From devising strategies with our companion journals Practical Neurology and the Journal of NeuroInterventional Surgery, with pearls and insights from their Editors and teams, most particularly Charles Warlow and Rob ('Tobby') Tarr. And most importantly throughout this journey, the weekly JNNP Hanging Committee meetings convened across the globe with Satoshi Kuwabara

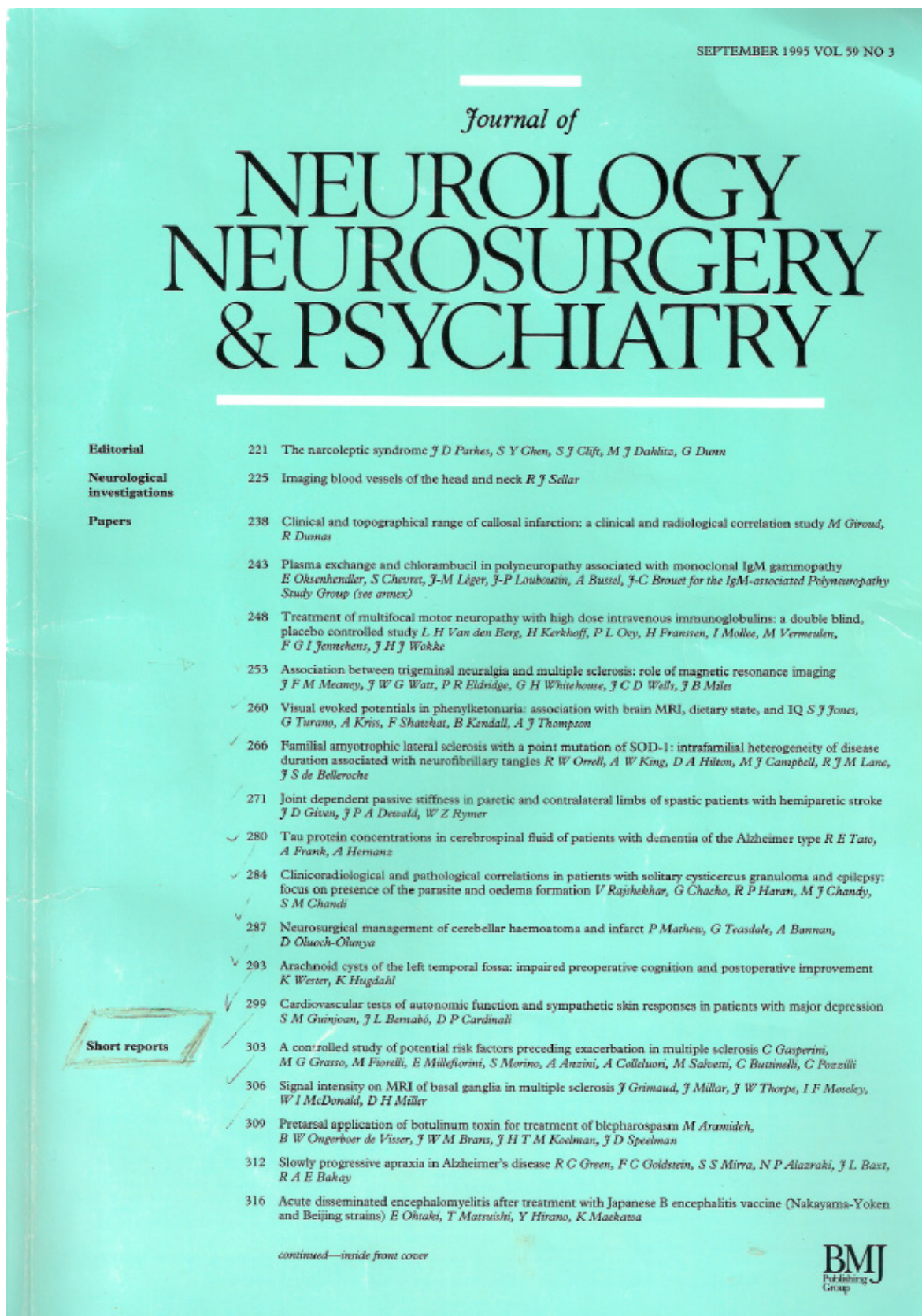

Figure 1 My JNNP copy circa 1995, learning the craft of neurology. 
in Japan, Karen Furie and Peter Warnke in the USA, Lawrence Wong in China and Nick Ward and Alan Carson in the UK. Launched from the shoulder of that giant Kinnier Wilson, the Marco Polo of the basal ganglia, we have learnt a great deal about our shared interests across neurology, neurosurgery and psychiatry, and key developments past, current and future. In both unlocking future citation classics and highlighting the impact of JNNP's stellar back catalogue with present-day reinterpretations, the journal has gone from strength to strength, with highlights that include the unlocking of disease pathophysiology ${ }^{78}$ to the circuitry of memory, ${ }^{910}$ the establishment of disease rating scales ${ }^{1112}$ to the advent of new therapies, ${ }^{13}$ and the consequent improvements in quality of life for patients confronted with life-changing disorders of the brain and mind. ${ }^{14} 15$

Along the way, the editorial process has been streamlined, aligned with the introduction of rapid online publication. Submission rates have risen to more than 3500 per year, while the various journal metrics have moved ahead in positive directions. Accepting that impact factor is an arbitrary index, ${ }^{16}$ breaking through the barrier of 10 in the least reflects greater citation rates for those studies that we have promoted over recent years, in turn reflecting ongoing and lasting impact across the field.

And so JNNP continues its regeneration with the launch of a new editorial team next year.
A new external realm of the brain awaits. $^{17} 18$

\section{Twitter Matthew C Kiernan @jnnp_bmj}

Funding The authors have not declared a specific grant for this research from any funding agency in the public, commercial or not-for-profit sectors.

Competing interests None declared.

Patient consent for publication Not applicable.

Provenance and peer review Commissioned; internally peer reviewed.

(c) Author(s) (or their employer(s)) 2021. No commercial re-use. See rights and permissions. Published by BMJ.

\section{Check for updates}

To cite Kiernan MC. J Neurol Neurosurg Psychiatry 2021:92:1249-1250.

Received 6 October 2021

Accepted 6 October 2021

Published Online First 25 October 2021

J Neurol Neurosurg Psychiatry 2021;92:1249-1250. doi:10.1136/jnnp-2021-328176

\section{ORCID iD}

Matthew C Kiernan http://orcid.org/0000-0001-9054026X

\section{REFERENCES}

1 Greene G. The end of the affair. United Kingdom: Heinemann, 1951.

2 Selby G, Lance JW. Observations on 500 cases of migraine and allied vascular headache. J Neurol Neurosurg Psychiatry 1960;23:23-32.

3 Burke D, Andrews CJ, Lance JW. Tonic vibration reflex in spasticity, Parkinson's disease, and normal subjects. J Neurol Neurosurg Psychiatry 1972;35:477-86

4 Kiernan MC, Hart IK, Bostock H. Excitability properties of motor axons in patients with spontaneous motor unit activity. J Neurol Neurosurg Psychiatry 2001;70:56-64.

5 Kiernan MC. Why an Australian editor for JNNP? J Neurol Neurosurg Psychiatry 2010;81:1.

6 Kiernan MC. Jewels in the crown: a century of achievement. J Neurol Neurosurg Psychiatry 2020;91:1-2. doi:10.1136/jnnp-2019-322443

7 Hughes AJ, Daniel SE, Kilford L, et al. Accuracy of clinical diagnosis of idiopathic Parkinson's disease: a clinico-pathological study of 100 cases. J Neurol Neurosurg Psychiatry 1992;55:181-4.

8 Lees AJ. The relevance of the Lewy body to the pathogenesis of idiopathic Parkinson's disease: accuracy of clinical diagnosis of idiopathic Parkinson's disease. J Neurol Neurosurg Psychiatry 2012;83:954-5

9 Scoville WB, Milner B. Loss of recent memory after bilateral hippocampal lesions. J Neurol Neurosurg Psychiatry 1957:20:11-21.

10 Milner B, Klein D. Loss of recent memory after bilateral hippocampal lesions: memory and memories-looking back and looking forward. J Neurol Neurosurg Psychiatry 2016:87:230.

11 Hamilton M. A rating scale for depression. J Neurol Neurosurg Psychiatry 1960;23:56-62.

12 Nutt D. The Hamilton Depression Scale-accelerator or break on antidepressant drug discovery? J Neurol Neurosurg Psychiatry 2014;85:119-20.

13 Francis PT, Palmer AM, Snape M, et al. The cholinergic hypothesis of Alzheimer's disease: a review of progress. J Neurol Neurosurg Psychiatry 1999:66:137-47.

14 Schrag A, Jahanshahi M, Quinn N. What contributes to quality of life in patients with Parkinson's disease? J Neurol Neurosurg Psychiatry 2000;69:308-12.

15 Schrag A, Quinn N. What contributes to quality of life in Parkinson's disease: a re-evaluation. J Neurol Neurosurg Psychiatry 2020;91:563-5.

16 Kiernan MC. What is impact? J Neurol Neurosurg Psychiatry 2012:83:1-2.

17 Kiernan MC. The realm of neurology--past, present and future. J Neurol Neurosurg Psychiatry 2011:82:1.

18 The realm of Neurology. J Neurol Neurosurg Psychiatry 1920:1:67-9. 